\title{
Memória, passagens e permanência da tragédia na literatura alemã
}

\author{
Marcos F. Campos da Rocha ${ }^{1}$
}

\begin{abstract}
This paper aims to study the literary genre tragedy and investigate how it can be truly identified in the works of two authors of the German Enlightenment and Classicism: G.E. Lessing and F. Schiller. In order to reach this goal, it is necessary first to step back to the Greek antiquity and study the origins of this type of text. Additionally, some titles by Shakespeare and Racine will be taken into consideration as further support of our claims.
\end{abstract}

Key-words: German literature - tragedy - Lessing - Schiller.

Resumo: Este artigo tem como objetivo proceder a um breve levantamento do gênero tragédia e verificar até que ponto ele está realmente representado no Iluminismo e no Classicismo alemão dentro da obra de G. E. Lessing e de F. Schiller. Para tanto, é necessário recuarmos no tempo até a Antiguidade clássica e estudarmos os fundamentos desse tipo de texto. $\mathrm{O}$ exame de alguns títulos dos autores propostos será, antes, devidamente respaldado pela apreciação de dois estágios da história da tragédia: em Shakespeare e Racine.

Palavras-chave: Literatura alemã - Tragédia - Lessing - Schiller

Zusammenfassung: Absicht des Aufsatzes ist es, eine kurze Aufhebung der literarischen Gattung Tragödie auszuführen und nachzusehen, inwiefern sie in der deutschen Aufklärung und Klassik besonders in den Werken G. E. Lessings und F. Schillers tatsächlich dargestellt ist. Um dieses Ziel zu erreichen, ist es zuerst einmal notwendig zurück bis zur Antike zu greifen und dort die Grundlinien dieser Art Text zu studieren. Die Untersuchung mancher Titel der erwähnten Dichter wird noch präziser durch die Miteinbeziehung der Werke Shakespeares und Racines in diesen Beitrag.

Stichwörter: Deutsche Literatur - Tragödie - Lessing - Schiller

\footnotetext{
${ }^{1}$ Marcos F. Campos da Rocha é professor adjunto de Língua e Literatura Alemã do Instituto de Letras da Universidade Federal Fluminense - UFF. Email: mfqprojetoparamount2001@ yahoo.com.br
} 


\section{Memória}

Desde suas origens, nos séculos V e VI antes da era cristã, a tragédia se revelou como expressão de um momento de crise política quando as formas de governo na Grécia antiga se deslocavam da aristocracia para a democracia. Em tempos ainda mais remotos, quando essa transformação ainda não se havia manifestado, a arte literária dos gregos atingia um de seus clímaces nas epopéias. Esse gênero narrativo não conhecia o Estado em metamorfose. A epopéia como um texto de fundação apresenta heróis de caráter e vontade determinados, indivíduos prontos e acabados cujos papéis e missão eram cumpridos como verdades absolutas, sem qualquer hesitação, sem espaço para dúvidas ou contestações. O herói épico - pense-se em Aquiles, Paris ou Ulisses - vence obstáculos, conquista cidades, derrota monstros e todos os inimigos. No final, sua desgraça será mais obra dos deuses do que dos homens. Séculos mais tarde, eles fornecerão o modelo para os heróis da épica moderna, em outra clave, bem entendido. $\mathrm{O}$ enredo épico caracteriza-se pela sucessão de acontecimentos, de artimanhas, de grandes batalhas, de rivalidades e paixões que concernem não exatamente ao indivíduo, mas a um exército inteiro. Uma nação age em bloco, tem um único objetivo. Na grande epopéia de Homero, não há tempo para individualidades nem para psicologias. Trata-se de textos de identificação de uma nação cujas cidades, antes isoladas, se reconhecem dentro do mesmo rumo civilizador. Nesse conjunto, havia diferenças e ambições conflitantes (HAUSER 1980: 94ss), mas não suficientemente nítidas para enfraquecer as alianças ou descaracterizar o perfil comum.

Ao contrário do enredo dos romances que delas descenderiam milênios mais tarde, o enredo das epopéias é baseado no heroísmo, em ações espetaculares cujos protagonistas pertencem à classe dominante ou são semideuses ou ambos. $\mathrm{O}$ confronto se dá sempre com o estrangeiro, com os titãs, nunca com o poder estabelecido; não há lugar ainda para a contestação. O sentimento que rege o texto épico da Grécia Antiga é o de júbilo na participação de uma missão do Estado. Por isso, seus heróis já nascem perfeitos e assim seguem até o desfecho, imbuídos da total legitimidade de suas ações e convencidos da superposição sem sobras - de seu destino e das intenções de seu soberano. A epopéia clássica desconhece qualquer tipo de migração social para cima ou para baixo. O príncipe é o herói e as disputas de poder refletem-se ao nível dos deuses. Mas nesse âmbito, o discurso é o mesmo, não importando se divindade apadrinhe qual 
alteza. O desentendimento entre os poderosos do Olimpo se encaixa sem problemas na ordem estabelecida (HAUSER 1980: 102).

E essa ordem permaneceu por séculos intocada até ser revista, justamente no apogeu da Grécia antiga. Se fossem, hoje, comparadas com nossas democracias de traço ocidental qualquer uma das antigas cidades da dependência de Atenas pareceriam fortalezas do autoritarismo. O que realmente se deu foi a passagem de poder das mãos de uma aristocracia de sangue para uma aristocracia de meios e de poder político. É desse 'povo' que fala a história, ou seja, as cidades gregas do século V são governadas por seus patrícios. Nelas, as mulheres, os estrangeiros, os camponeses, servos e a raia miúda nunca tiveram voz (HAUSER 1980: 122). A participação era limitada aos que detinham poder econômico. A Grécia evoluiu apenas de um Estado de aristocracia de berço para uma plutocracia de fisiologistas através de um quadro identitário positivo, proporcionado pelas vitórias de Atenas nas Guerras Médicas contra os persas em 490 e 480 a. C. (ROMILly 2008: 184).

É neste cenário de rotação política que nasce a tragédia. Os fundamentos não são mais os de incontestável hereditariedade, mas sim aqueles já não tão sólidos dos quais se originam indivíduos desprovidos de certezas imbatíveis, desamparados eventualmente pelo deus que os protege. Mesmo que sejam tão aristocratas quanto seus adversários, a estes se opõem por uma questão de honra e de justiça pessoal. É preciso que se tenha em mente que a ética que move o príncipe na tragédia é a mesma para todas as partes, ainda que sejam antagonistas. Na tragédia, discute-se o ponto-de-vista diferente dentro da mesma perspectiva de mundo, da mesma casta social. O conflito se dá entre os notáveis e o que a tragédia traz de novo é o fator desconfiança, o fator desestruturante, na medida em que o contestador se vê na contingência de reivindicar contra um status quo que antes o amparava e que agora terá de enfrentar sozinho.

A Antígona de Sófocles (495-406), por exemplo, luta contra Creonte, rei de Tebas, a fim de render as honras funerárias a seu irmão Polinice, morto diante dos muros da cidade e ali deixado por ser considerado um traidor pelo rei. A fim de que Tebas não fosse destruída pelo exército comandado por Polinice, um dos filhos do incesto de Édipo com Jocasta, Etéocle, seu irmão, resolve destacar seis generais para lutar contra seis outros do exército oponente que ameaçava a cidade. Ele próprio, o sétimo, teve de enfrentar seu irmão num desses duelos. Como se vê em Édipo rei, talvez a tragédia maior de Sófocles e de todos os tempos, Édipo, filho de Laio e de Jocasta, 
mata, sem o saber, o próprio pai e casa-se, igualmente ignorante, com a própria mãe, dando origem a uma série de desgraças e fundando uma estirpe perseguida pela maldição.

Os enredos da tragédia se interceptam e derivam de situações que produzem outros enredos em um desenvolvimento contínuo de sucessivas ramificações. Elas remetem umas às outras, representando o entrelaçamento de destinos e a perpetuação de angústias que giram em torno do poder, da honra, do amor e do ódio, enfim, de paixões humanas.

O teatro clássico em sua expressão trágica mantém um ponto de vista aristocrático sobre o mundo. O conflito se dá nessa dimensão e nunca se origina nas camadas populares (HAUSER 1980: 123) como sucede nas comédias (MOISÉS 1999: 90) nas quais se encenam os costumes. Os autores das grandes tragédias eram, eles próprios, filhos da classe dominante ou com ela simpatizavam. Além disso, não viam com muita confiança os rumos que a democracia ateniense tomava, embora celebrassem suas conquistas.

A tragédia leva ao palco as lutas internas e a insegurança diante dessa sociedade de transição. De certa forma, a tragédia era um veículo de mediação do Estado. Tinha origens tanto na arte quanto na religião, no velho culto ao deus Dioniso (Baco para os romanos). Filho de Zeus e de Semele, ele fora arrancado do ventre da mãe, morta aos seis meses de gestação, e introduzido pelo pai entre os músculos da própria coxa. Nascido, assim, duas vezes, Dioniso torna-se um deus dos prazeres da vida. Os rituais em sua honra incluíam procissões que transportavam um enorme falo e utilizavam as máscaras que tinham a função de transferir a seu portador poderes mágicos (LESKY 2003: 58ss) os quais se perpetuaram na tragédia cujo tema é justamente a submissão dos homens a seus instintos: Édipo, que sucumbe vítima de seu desejo; Medea, na vingança assassina por ciúme de Jasão que a abandona por Creusa, filha de Creonte, rei de Corinto; Antígona, que, sob o império da consciência individual, sucumbe diante de outro Creonte, irmão de Jocasta e sucessor de Édipo em Tebas; Clitemnestra, inconformada com o sacrifício da filha Ifigênia ordenado pelo próprio pai, dá cabo do marido - Agamênon - o legendário conquistador de Tróia, também executor de Cassandra, a sacerdotisa troiana; Oreste, filho do precedente, vinga-se da mãe, Clitemnestra, e do amante desta, Egisto, com a ajuda de sua irmã, Elektra. 
Campos da Rocha, M. F. - Memória, passagens e permanência da tragédia

As tragédias gregas são um produto de um momento especial da política ática em fase de transição e um instrumento de legitimação da nova ordem, portanto, interessada em desacreditar a anterior. Representadas nos grandes anfiteatros ao ar livre, as tragédias se produziam em períodos regulares a cada ano dentro de um evento maior, de um festival, no qual os novos textos eram encenados no âmbito de um concurso que recebia, ao contrário do teatro realmente popular (farsa mimada), subvenção e diretivas do poder (HAUSER 1980: 125).

Por isso, o conteúdo dos textos, por mais patéticos, virulentos e assustadores que possam parecer não deveriam contrariar a estrutura dominante do governo que então se instalava. Ao longo de seus episódios, não se vê qualquer veleidade de cunho crítico ou revolucionário. Por servir de base moral à classe arrivée, o herói trágico simbolizava o fim que o destino reservava aos antigos soberanos (HAUSER 1982: 745) e do qual, por contraste, deveria preservar os novos. A tragédia era um texto previamente autorizado nesses termos e legitimava habilmente a nova estrutura através de vocabulário e conceitos já conhecidos. HAUSER (1980: 128) alerta para o fato de que a tragédia era um drama político, construído a partir da tradição, da lenda e do mito, mas de temática estritamente citadina, da polis, portanto político a partir desse ponto de vista. Ao mesmo tempo, a tragédia se constituía num meio de catarse e de entretenimento que satisfazia tanto o lado racional como o irracional, os hemisférios dionisíaco e apolíneo da natureza humana. Meio-termo conveniente entre religião, arte e forum de debate público, a tragédia encenava o conteúdo - possivelmente histórico - deste último valendo-se da forma do primeiro (id.).

À época de Aristóteles (384-322), a tragédia grega já havia atingido o seu ápice. Ésquilo (525-456), considerado o fundador da tragédia grega e autor de mais de oitenta peças nos é conhecido apenas pelos textos das sete que sobreviveram, dentre elas As suplicantes, Os sete contra Tebas e a trilogia Orestia (RomILly 2008: 54). Sófocles (496-406), que introduziu significativas reformas no gênero, deve seu renome a mais de cem textos deste gênero dos quais apenas sete atravessaram os tempos. Édipo rei é seu título mais celebrado e considerado o texto trágico por excelência, mas se faz acompanhar de outros de quilate semelhante como Elektra, Édipo em Colona e Antígona. O mais jovem dos três grandes nomes da tragédia grega é Eurípedes (480406), amigo de Sócrates, e desaparecido no mesmo ano em que morreu Sófocles. Apenas dezoito das mais de noventa tragédias escritas por ele chegaram aos nossos dias. 
Introdutor de um estilo mais conciliador e menos determinado sobre a ruína dos indivíduos, conhecemos dele títulos como Ifigênia em Aulis, Medea, Alceste e Elektra. Tendo vivido cem anos após esses três expoentes do gênero, o sábio de Estagiros já reunia condições suficientes para estudar esse tipo de teatro que deveria "suscitar terror, piedade e ter por objetivo a purificação, a catarse" (MOISES 1999: 496) dos sentimentos. O teatro trágico era encarado como um educador de emoções surgidas naquele momento, ou antes. A representação devia ser, por isso, uma oportunidade para o público de reelaborar em si, através do mito emblemático, um luto, uma frustração ou mesmo um antagonismo à espera de compensação (HAUSER 1980: 126).

Se compararmos as datas de nascimento e morte dos três maiores nomes da tragédia grega, Ésquilo, Sófocles e Eurípedes - vale lembrar que houve vários outros autores de tragédias naquela época, além deste trio mais celebrado (ROMILLY 2008: 186) - poderemos ver que eles conviveram na Atenas em sua época mais brilhante, à proa da Liga de Delfos que derrotou os imensos exércitos persas e levou a civilização grega ao seu terceiro ou quarto apogeu. Se considerarmos períodos anteriores igualmente espetaculares como a civilização cretense, ainda no segundo milênio antes de Cristo, a renascença grega no nono século, quando nasceram os jogos olímpicos, a expansão das colônias gregas por todo o Mediterrâneo, no século sétimo, sem esquecermos o primeiro período de tirania, época de grande desenvolvimento cultural no século sexto, nos damos conta dessa trajetória.

O tempo da tragédia grega é, portanto, o tempo da Atenas clássica, de Sócrates e de Xenofonte, de grandes escultores e arquitetos. Durante os dois ou três séculos do florescimento de Atenas, é, contudo, desconcertante a evolução desse gênero de literatura. Mesmo no curto espaço de tempo que se estende entre Ésquilo, o mais velho dos três maiores dramaturgos, e Eurípedes, o mais novo, percebe-se que a tragédia se desloca de uma estrutura mais rígida para outra mais flexível. Se, em Sófocles, encontramos a expressão mais pura do gênero que se manifesta na irredutibilidade do destino de Édipo, aos poucos, nos damos conta que os entrechos estão menos impelidos à desgraça e ao horror. Segundo Arnold HAUSER (1980: 136), o acordo final não colocaria em risco a integridade da natureza trágica dos acontecimentos. O poder inicial da maldição vai cedendo lugar a uma psicologia mais refinada, em direção ao sofrimento menos marcado pela mão inexorável do fado (id.). 
Com efeito, situada já no limiar da passagem do período helênico para o período helenístico, a arte de Eurípedes, o mais novo da tríade fundamental, já propõe uma saída reconciliatória para os impasses experimentados por seus heróis, os quais são, muitas das vezes, heroínas. Através delas, introduz-se o tema do amor com mais desenvoltura na tragédia (Alceste). Este deslocamento do eixo dramático de assuntos mais objetivos para um cenário mais lírico se deve também, em parte, ao fato de Ésquilo, o mais antigo, ter sido militar; Sófocles, um dignatário sacerdotal e Eurípedes um intelectual mais afeito às aflições do homem comum, mesmo que tivesse trabalhado como preceptor apenas de jovens de famílias ricas (HAUSER 1980: 138).

De qualquer maneira, o centro da ação mantinha-se no mito que remontava à época heróica da Grécia, a qual lograva transmitir às novas gerações um legado de valores de origem guerreira, uma herança que nunca foi e nem pôde ser negada (HAUSER 1980: 172). Mergulhado na aurora dos tempos, o patrimônio mítico que servia de nascedouro dos temas sempre recorrentes das grandes tragédias permanecia envolto pela neblina da religião, mas era reinterpretado pelo olhar da polis que via no mito o veículo ideal para a encenação de seus próprios incidentes (HAUSER 1980: 543).

\section{Passagens}

Ainda que tenha experimentado um período de reconhecimento em Roma através de Sêneca, a tragédia como gênero vai desaparecer durante toda a Idade Média para só se recuperar na Espanha, com Calderón de la Barca, e na Inglaterra, com Shakespeare. Por fim, atingirá um segundo ponto alto em sua história durante o Classicismo francês com Corneille e Racine. A sua eclipse medieval pode ser entendida, se nos dermos conta de que toda a tradição grega e romana foi devidamente interditada pela fé católica durante os séculos nos quais a filosofia e arte estiveram a serviço da nova religião. Uma reflexão mais demorada nos permite afirmar que o exercício da fé, sobretudo antes do Renascimento, não deixava margem para dúvidas. Imbuído das certezas da doutrina, o indivíduo não se colocava em xeque, isto é, não se via em contradição. O motor maior da tragédia na Grécia era a inexorabilidade do fato e do fado, tramas do "conflito trágico cerrado" (LESKY 2006: 55) contra o qual não havia escape. 
O Cristianismo pretendeu suprir essa saída. Contudo, o martírio dos santos não pode ser interpretado como uma atitude trágica, uma vez que seu flagelo era consequência da fé inabalável e não de desespero. Não se via qualquer hesitação a esse respeito, uma vez que seu destino não era por eles encarado como vingança ou produto de qualquer outra paixão material. Tampouco havia qualquer espaço para digressões políticas, numa época de invasões bárbaras, migrações generalizadas na Europa central, setentrional, meridional e oriental, e muito menos até o fim das Cruzadas, um conjunto de sete ou oito enormes empreendimentos que se estenderam por quase dois séculos (1095-1290). O fim das Cruzadas marca o início do Renascimento na Itália com a poesia de Dante, a arte de Giotto e sintomaticamente a instituição do Santo Ofício, da Inquisição. No entanto, a dúvida, a encruzilhada, a tomada de decisão, o ser ou não ser passam crescentemente a assombrar o homem renascentista, no esforço de se emancipar da tutela transcendental. Instalava-se, naquele momento, uma "transgressão social" através da qual um paradigma civilizatório começava a substituir outro, ou seja, o advento da Renascença e do Barroco com suas dúvidas, reformas, descobertas e longos conflitos que pareciam se configurar como um novo cenário adequado para a tragédia (HAUSER 1982: 745).

O teatro de Shakespeare é a expressão dessa condição. Nunca um de seus heróis apela a Deus. Otelo se deixa envolver numa rede de dúvidas e intrigas e é perseguido até o fim pelo demônio do ciúme, sem ceder um instante sequer aos céus ou à razão. Hamlet, por certo, vinga-se da mãe e do padrasto não sem antes hesitar a respeito de suas convicções. Foi preciso que o fantasma do pai lhe aparecesse mais de uma vez para empurrá-lo à ação. Mesmo assim, Lionel ABEL (1968: 65) argumenta que o ódio de Hamlet pelo tio o exime de qualquer responsabilidade trágica, uma vez que o príncipe já odiava o usurpador. O mesmo crítico se pergunta por que o fantasma não ordenou a Hamlet que matasse sua mãe, o que lhe teria certamente conferido perfil trágico. Um herói trágico não deveria se dar ao luxo da indecisão, embora seja este o maior tormento do fidalgo dinamarquês (ABEL 1968: 69). O perfil de Macbeth, ao contrário, já é bem outro. De fato, ele chega a passar uma noite em claro, mas afinal decide-se pela ação; é o personagem shakespeariano de traço mais nitidamente trágico (ABEL 1968: 21). Essa condição torna-se explicitamente determinada a partir do momento em que Macbeth entra num turbilhão de decisões e de ações do qual não há mais volta (ABEL 1968: 22s). As desgraças se sucedem por sua mão, conduzida em boa parte por Lady Macbeth, um 
personagem de pragmatismo diabólico. Vários outros elementos contribuem para que este texto se revista de uma atmosfera plena de agouros e de contatos com o plano do maravilhoso que constroem, em parte, um cenário onde poderes exteriores - nesse caso, do inferno e não do Olimpo -, têm um papel a cumprir: feiticeiras, profecias, fantasmas e florestas acentuam as notas trágicas que anunciam situações irreversíveis, porém perfeitamente coadunadas com a ambição sem limites de Macbeth.

O teatro elisabetano é ainda anterior à Revolução Gloriosa que antecedeu a Revolução Francesa em cem anos e concedeu à Inglaterra uma maturidade civil que tornou a monarquia um exercício de poder sujeito a regras e limites que os outros soberanos da Europa não conheciam. Assim como já ocorria no teatro grego, o texto de William Shakespeare não esconde o caráter moralizador que lhe é intrínseco. Seu autor não tem delírios revolucionários; levar ao palco vícios de uma realeza remota no tempo ou no espaço não era comprometedor para ele. O mesmo pode ser dito em relação a outro grande artista da tragédia em pleno Classicismo francês: Jean Racine (BARTHES 1987: 153).

Em momento algum, Racine pretendeu contestar o regime que o sustentava e no qual ele reconhecia total legitimidade. Educado no jansenismo, uma dissensão holandesa praticada na abadia católica de Port-Royal, Racine cedo aprendeu a ler os clássicos gregos e é orientado religiosamente mais pelo Antigo do que pelo Novo Testamento (ABEL 1968: 32). Trata-se de restituir a graça e salvar-se pela reconciliação ou ter a coragem de romper. No entanto, como diz Roland BARTHES (1987: 33), "reclama-se sem se revoltar". O teatro de Racine pretende pôr em cheque a relação do homem com Deus. Ainda no entendimento de BARTHES (1987: 133), não existe tragédia sem esse impasse. O desafio aponta para a vontade de um novo nascimento cujo preço pode ser alto demais, mas que deve ser aceito pelo herói trágico que não transigirá. Contudo, por mais radical que seja a posição do desafiante, o texto em Racine mantémse dentro dos limites do acordo político, assim como no teatro grego. Toda revolta trágica dirige-se mais contra o destino, contra a lei de Deus ou contra um capricho dos deuses, ou, no limite, contesta um soberano, não por sua maneira de governar, mas por uma questão particular. Sua literatura foi produzida em época de grande opressão civil, e não se encontrará em Racine nenhum motivo de ordem explicitamente política (ABEL 1968: 52). Por outro lado, admite-se, dentro de certos parâmetros, a discussão sobre os fundamentos da fé na França setencentista, já chamuscada por uma série de conflitos 
Campos da Rocha, M. F. - Memória, passagens e permanência da tragédia

religiosos, mas ainda sujeita a graves recaídas da opinião do rei que, por influência jesuítica, perseguiu os jansenistas e revogou o Edito de Nantes.

A tragédia francesa é eleita como o teatro da corte porque seus temas são aqueles do classicismo da Antiguidade ou da parte primeira da Bíblia, a qual admitia uma especulação que a França, dentro de um impulso renascentista e erudito, queria cultivar. Os temas serão antes de natureza existencial mais abrangente como o amor não realizado (Fedra), a religião (Ester e Atália), o conhecimento (Ifigênia) ou a sujeição (Bezajet). Por mais fiel que Racine tenha se mantido às regras de Aristóteles (ABEL 1968: 52), ou tenha adotado outras que configuram as três unidades de tempo, de tema e de lugar, e tenha, até mesmo, incluído um elemento tipicamente grego como o coro em Ester e em Atália, seu teatro já se preparava para um afastamento do gênero trágico. A presença do coro nos textos citados cumpre a função prevista por Aristóteles (id.: 54): de comentar o rumo dos acontecimentos e de anunciar a catástrofe por vir. Racine despede-se das tragédias de traço irredutível após Fedra (BARTHES 1987: 149).

O divórcio de Racine desse tipo de texto é marcado pelas peças de caráter conciliatório, numa trajetória que lembra a de Eurípedes, mais de dois mil anos dele distante. O impasse fundamental é resolvido através ou de um acordo ou da morte do antagonista. Esse rompimento com a tragédia de corte ortodoxo pode ter-se dado por motivos circunstanciais: Luiz XIV preferia as peças que terminassem em entendimento (BARTHES 1968: 54). Como o autor não podia arriscar perder o patrocínio, ele dará, a partir daí, preferência a heróis de cunho cada vez mais burgueses e de caráter mais psicologizado (id.: 137). A intenção passa a ser a de conferir ao novo teatro um estatuto de teatro clássico, mas a tendência psicologizante dos textos posteriores, ao longo da história da literatura, é inevitável. Os deuses se despedem e deixam no lugar o comportamento racional voltado para a reconciliação. O exílio de Deus anunciaria a morte da tragédia?

\section{Permanência}

O Iluminismo alemão, dentro do espírito otimista e conciliador da Aufklärung, encontra sua expressão para o teatro nas páginas de Lessing, porém nem Emilia Galotti tampouco Nathan der Weise poderiam ser enquadrados como tragédias, pois falta-lhes aquilo que 
Schelling identificava como indispensável ao herói trágico: a ação a partir do seu motor fundamental - a necessidade intrínseca (SZONDI 2004: 32). Galotti é vítima de um plano sórdido e da intransigência do pai. Não se pode imputar-lhe nenhuma responsabilidade. Nathan é um filósofo cujo objetivo é demonstrar uma tese. Nenhum dos dois está imbuído de uma certeza inquestionável, nem de um ímpeto incontido. Além disso, no âmbito da forma, Lessing já havia se comprometido com um programa de revisão e crítica ao teatro clássico de Corneille e Racine, ainda na primeira metade do século XVIII, defendido por Gottsched. Sua Dramaturgia de Hamburgo argumentava que a Alemanha deveria se emancipar desse modelo e construir um repertório próprio de inspiração liberal.

Lessing acreditava que o ambiente e a forma rígida das três unidades - de tempo, de lugar e de tema - já estavam ultrapassadas e que era preciso recriar o teatro transpondo para a esfera burguesa o drama de uma classe em tímida ascensão na Alemanha (SCHLOSSER 1994: 143). E como toda classe em ascensão procura ser aceita, sobretudo pelos que ainda tem a voz de mando, o teatro burguês de Lessing, por mais esclarecido e até emancipador que possa parecer, é um teatro de índole conciliatória. Sua crítica aos abusos do absolutismo se desloca para outras latitudes para evitar problemas com a censura, mas as entrelinhas são suficientemente largas para permitir boa leitura e transmitir o recado. A questão é a classificação: mesmo o conceito de tragédia burguesa parece fora de lugar. De qualquer maneira, já se intuía que a queda exemplar (LESKY 2006: 32) poderia ser também aplicada ao homem comum e, mais importante, que o desafio antes lançado ao destino através de um enfrentamento com Deus(es) poderia ser transferido para um enfrentamento com leis e tiranos despóticos, o que, de fato, já acontecia desde os clássicos gregos, só que desta vez, sem ajuda ou participação de qualquer Olimpo. Ou seja, o pequeno herói plebeu se encontrava igualmente em condições de se lançar da altitude trágica. Contudo, na época de Lessing, uma classe que pretendia ser reconhecida deveria ser cuidadosa ao contestar. SCHLOSSER (1994: 143) nos lembra que o próprio vocabulário escolhido pelo iluminista dá conta disso, ainda que em termos teóricos dentro da sua Dramaturgia: O espectador deve compartilhar o medo, mas não o terror. Anatol RoSENFELD (1993: 216) formula com maior acerto: 
O terror estabelece um abismo entre o palco e a platéia, mostrando-nos destinos horripilantes de reis com quem não podemos identificar-nos. $\mathrm{O}$ medo, ao contrário, é suscitado pelo sofrimento de nossos semelhantes, sofrimentos que podem atingir a nós mesmos a qualquer momento. O terror liga-se ao destino temível dos grandes à queda deles de augustas alturas.

Seria o medo um sentimento mais de acordo com a racionalidade iluminista e o terror um sentimento de épocas nas quais reinava o arbítrio descontrolado de um soberano moral e "politicamente" condenável, cuja identificação pelo público poderia constranger a maioria dos príncipes alemães? Seja como for, o terror vibra outras cordas da sensibilidade, pois sabemos da inexorabilidade do destino sobre os dias do herói. A influência de Lessing pode ter sido de alcance limitado sobre os séculos XVIII e XIX na Alemanha, ainda muito tímida e indecisa a respeito de sua vocação iluminista que descambou para um Idealismo que passou ao largo das questões civis e se concentrou em estudos de juízo, de história e de estética.

A trajetória de Friedrich Schiller (1759-1804) apontava para uma continuidade do itinerário de Lessing. Superada e renegada sua fase pré-romântica do Sturm und Drang, o grande poeta suábio envereda por uma trilha cujos indicadores de direção apontavam para as vias da emancipação. Contudo, seu caminho contorna os trechos mais íngrimes do Iluminismo e percorre as paisagens menos abruptas do Classicismo. De fato, sua arte já não é mais aquela de arroubos e impetuosidades das cenas curtas e tempestuosas de seus Salteadores. O drama de Schiller toma rumo paralelo ao de Lessing e se refugia na história de países estrangeiros (Carlos, Orléans, Tell e Stuart) ou remotamente alemães (Wallenstein) para encenar os impasses gravíssimos do absolutismo. Mas poderão esses textos ser considerados tragédias? Goethe renunciara conscientemente a elas devido à sua posição política e à sua natureza pessoal conciliatória (SzONDI 2004: 48). Sua opinião era de que a expressão trágica permanecia irredutível, isto é, não admitia qualquer possibilidade de acordo. Os heróis de Schiller, com exceção de Guilherme Tell, sucumbem todos diante do poder, mas também o revolucionário suíço é posto à prova pelo tirano Gessler da maneira mais cruel. Além disso, não lhes faltava uma necessidade, fosse ela a de libertar a pátria de um jugo, de rechaçar os inimigos ou de salvar a própria pele. Possuíam, portanto, um projeto, um objetivo, uma determinação. Entretanto, nenhum deles é um herói realmente burguês, pois estavam a serviço de outros pontos de vista; os que eram aristocratas tinham caído em suas respectivas desgraças. Faltar-lhes-ia paixão? 
Campos da Rocha, M. F. - Memória, passagens e permanência da tragédia

Talvez a grande diferença seja a de que alguns heróis de Schiller sejam, a princípio, revolucionários e os heróis gregos, não. Estes agem por uma questão de direito intrínseca à sua posição. Impõe-se-lhes uma situação de impasse existencial, mas nunca de impasse político, pois nenhum deles contesta a natureza do poder. Possuiriam os protagonistas de Schiller a índole revolucionária que os elevaria, por certo, a altitudes trágicas? Estudioso atento da história, Schiller colocou seus heróis dentro desta perspectiva, ela própria sujeita às contingências existentes em seu país, o Württenberg do sudoeste alemão, governado por um déspota muito pouco ou nada esclarecido cuja intransigência obrigou o escritor a se refugiar em Estados vizinhos e lá encenar seus textos.

Por outro lado, o atendimento a alguns aspectos formais da tragédia clássica, como a inclusão de coros em Die Braut von Messina favoreceria sua classificação como tal, mesmo que falte a esta peça de Schiller um motivo de natureza existencial mais contundente? Ou estaria Schiller consciente de seus limites, conferindo ao texto, através do coro, apenas um elemento que ajudaria a sublinhar a poesia nas falas e, assim, a intensificar a experiência artística (BAUMANN e OBERLE 1996: 111)? Tentemos, então, outra formulação.

A força da identificação subtrai-se aos seus protagonistas, pois eles se mantêm na condição de mártires ou de heróis frustrados cujo impasse não propicia a identificação catártica, não se transfiguraram em matéria épica; tampouco seus traços alcançaram a dimensão do mito. Anatol RoSENFELD (1993: 75) se refere a uma "liberdade íntima" desses destinos que evoluem em um espaço à parte, num vácuo afetivo no qual a identificação com o espectador ou com o leitor é mediada ou talvez diluída pela importância do fato histórico e da extensa retórica, sempre relevantes para Schiller (STEINER 2006: 99), mas que deixam em segundo plano a angústia humana, pessoal.

Tentemos, agora, uma revisão: nem os grandes nomes da tragédia na Grécia tampouco Shakespeare ou Racine contestaram seus reis. O clássico francês foi suficientemente hábil e cauteloso ao ambientar suas tragédias fora da França e nas longínquas épocas de heróis e mitos. A própria Grécia antiga, ao contrário, era palco dos textos de seus dramaturgos porque possuía material épico suficientemente sedimentado e identificado pela polis (LESKY 2006: 43 e 131). 
Lessing elege o homem comum e desloca a ação para fora da Alemanha. Esse recurso não ameaçaria a estrutura da tragédia, se este homem comum protagonizasse o texto de forma suficientemente trágica; isto só se dá quando o personagem é confrontado com uma questão incontornável para sua existência e enfrenta a inexorabilidade do destino (LESKY 2006: 55) através da suprema necessidade de uma decisão (SZONDI 2004: 32).

$\mathrm{O}$ fato de o enredo ser transportado confere à trama um ponto de contraste significativo, no entanto, a transferência não será grave se a matéria dramática transcender o mero registro histórico e alcançar o âmbito do mito (LESKY 2006: 78), onde residem as paixões humanas, como o fez Racine. Além disso, Lessing não lhes atribui coragem o suficiente para encarar o arbítrio. Ou seja, tanto o Iluminismo como o Classicismo alemão produzem textos nos quais se nota um substrato trágico que, no entanto, parece estranhamente diluído.

Ao contrário de seus antecessores, os poetas alemães já estavam suficientemente amadurecidos para reconhecer o estado de coisas dentro de suas respectivas fronteiras e na Alemanha em geral. E, uma vez reconhecidas estas circunstâncias, não havia mais o que se fazer. Otto Maria CARPEAUX (1968: 73 e 76) refere-se a uma revolução que se passa só no pensamento. No entanto, é curioso observar como os heróis de Schiller se encaixam bem dentro de cenários trágicos. Sequer lhes faltaria outro elemento intrínseco da épica também presente na tragédia clássica, que é a distância cronológica que confere aos personagens credibilidade e dimensão histórica.

Sem dúvida, certo número de elementos parece ser indispensável ao texto trágico a fim de que ele se caracterize como tal. Albin LESKY (2006: 33) prioriza a preponderância da ação sobre qualquer elucubração de ordem psicológica. George STEINER (2006: XVIII) atribui grande importância à consciência a respeito do próprio desamparo metafísico por parte do herói. A essas rubricas poderíamos acrescentar o fator identificação, catártico de todo texto trágico, o qual deverá conter em si elementos suficientes a proporcionar reconhecimento e legitimação do sofrimento por parte do leitor ou espectador. Elementos de ordem universal que ecoam em cada coração e mente e conferem ao texto trágico uma fonte de identificações e estão além das circunstâncias geográficas e históricas em que são ambientados.

O talento de Schiller estava pronto para outorgar ao classicismo alemão um grande texto trágico que estivesse de acordo com a consciência de seu autor. Mas isto 
Campos da Rocha, M. F. - Memória, passagens e permanência da tragédia

teria representado um enorme risco político e um retorno aos ímpetos do Sturm und Drang do qual o poeta já havia se despedido. Seu projeto trágico teria se realizado com mais nitidez em Demétrio. O personagem-título não se envolve com qualquer questão politicamente contestatória, senão com o tema de sua própria legitimidade (SzONDI 2004: 119ss). No início, tomado como verdadeiro sucessor do tzar, ele acaba por se ver e se construir como tal, mesmo sabendo que era um usurpador. Quando a verdade lhe é finalmente revelada, ele luta desesperadamente consigo mesmo para manter-se impávido no poder. O conflito se dá dessa forma porque ouviu sozinho a revelação da boca de um mensageiro que é imediatamente assassinado. A tragicidade de Demétrio é, assim, de ordem estritamente pessoal e, de certa forma, diz respeito a cada um de nós preocupados que estamos em conferir a maior legitimidade possível à nossa existência. A trama, entretanto, toma outros rumos. Demétrio é, por sua vez, eliminado e a sucessão ao trono se transforma em mera corrida de obstáculos. Aquilo que se configurou tão nitidamente como cenário trágico, acaba por se mostrar como um drama de boulevard. Afinal, se aquele cuja necessidade intrínseca era se afirmar como alguém que ele não era, uma vez eliminado de cena, o texto, que antes detinha alto potencial de tragicidade, se perde. Aos pretendentes ao trono faltavam início e fim de um mesmo caminho: destituídos de uma necessidade existencial incontornável - afirmar-se como indivíduo estavam apenas interessados em fazer valer suas prerrogativas dinásticas. Nenhum deles se inseria numa problemática que, segundo Scheler (apud SzONDI 2004: 73) define-se como "a dialética própria da tragédia", a saber, aquilo que deveria proporcionar a elevação do indivíduo, no caso de Demétrio, sua (auto)afirmação como monarca, acaba se tornando o motivo de sua perda.

\section{Perspectivas}

Nem Lessing nem Schiller puderam (ou não acharam conveniente) encenar a questão da menoridade civil burguesa. A tragédia autêntica do Iluminismo alemão teria sido esse enfrentamento, mas no lugar dele o que se tem são enredos transplantados, exilados em outros tempos e espaços cujos heróis por vezes se encaixam com dificuldade no perfil trágico mais ortodoxo. De qualquer forma, é sintomático que tanto Schiller quanto Lessing tenham sido autores proscritos no III.Reich. A draconiana censura nacionalsocialista suspeitava de qualquer texto que insinuasse reivindicar liberdade, não importa 
Campos da Rocha, M. F. - Memória, passagens e permanência da tragédia

em que registro dramático. A Alemanha do pós-guerra reabilitou esses autores em boa hora, pois a população alemã ansiava por textos nacionais que ilustrassem de modo suficientemente claro os abusos do poder. A ascensão da burguesia e, com o tempo, da classe operária nas democracias de traço ocidental acabou por formar um novo cenário de contingências que ultrapassa o antigo forum aristocrático e se expande por toda a sociedade. $\mathrm{O}$ drama substitui as tragédias, mas herda delas uma tensão, um impasse a superar. Nos textos mais significativos, é o indivíduo anônimo erguido à altura trágica e exemplar. Seus algozes não são mais reis, deuses ou príncipes infiéis, mas sim aquilo que se encontra mais perto dele e que deveria ser o motivo de sua redenção: a Modernidade. No entanto - a cada época sua tragédia específica - nas sombras de sedutores labirintos vagueiam outras criaturas que engendram secretamente sua perda.

\section{Referências bibliográficas}

ABEL, Lionel. Metateatro. Rio de Janeiro: Zahar, 1968.

Baumann, B.; Oberle, B. Deutsche Literatur in Epochen. Ismaning: Max Hueber, 1996.

BARTHES, Roland. Sobre Racine. Porto Alegre: L\&PM, 1987.

CARPeaux, Otto M. A literatura alemã. São Paulo: Cultrix, 1964.

ÉsQuilo. Oréstia: Agamênon, Coéforas, Eumênides. Rio de Janeiro: Jorge Zahar, 1991. . Os sete contra Tebas. Porto Alegre: L \& PM, 2007.

EuRÍPEDES. Alceste, Electra, Hipólito. São Paulo: Martin Claret, 2003. As fenícias. Porto Alegre: L \& PM, 2005.

HAUSER, Arnold. História social da literatura e da arte. v.1, São Paulo: Mestre Jou,1980. HAUSER, Arnold. História social da literatura e da arte. v.2, São Paulo: Mestre Jou, 1982. LESKY, Albin. A tragédia grega. São Paulo: Perspectiva, 2006.

Lessing, Gotthold E. Emilia Galotti. São Paulo: Ed. Peixoto Neto, 2007. .Werke. München: Carl Hanser Verlag, 1971. 2. Bd.

MoISÉs, Massaud. Dicionário de termos literários. São Paulo: Cultrix, 1999.

RACINE, Jean. Théatre complet. Paris: Garnier-Flammarion, 1964.

RoMiLly, Jaqueline. A tragédia grega. Lisboa: Edições 70, 2008.

RosEnFELD, Anatol. História da literatura e do teatro alemães. São Paulo: Perspectiva; EDUSP; Campinas: Ed. da UNICAMP, 1993.

SCHILLER, Friedrich. Dramen. Wien: Ullstein, 1947. 2 Bd.

SCHLOSSER, Horst. DTV-Atlas zur deutschen Literatur: Tafeln und Texte. München: DTV, 1994.

ShaKeSPEARE, William. Otelo. São Paulo: Martin Claret, 2005. Macbeth. Porto Alegre: L \& PM, 2006. 
Campos da Rocha, M. F. - Memória, passagens e permanência da tragédia

Hamlet. Porto Alegre: L \& PM, 2007.

Sófocles. Antígona. Porto Alegre: L \& PM, 2006.

Édipo Rei. Porto Alegre: L \& PM, 2007.

STEINER. George. A morte da tragédia. São Paulo: Perspectiva, 2006.

SzONDI, Peter. Ensaio sobre o trágico. Rio de Janeiro: Jorge Zahar, 2004.

Recebido em 30/04/2010

Aprovado em 08/10/2010 